\title{
Ocena aktywności wybranych osuwisk w rejonie Jeziora Rożnowskiego w świetle badań terenowych oraz analiz różnicowych modeli terenu
}

\author{
Marcin Wódka ${ }^{1}$
}

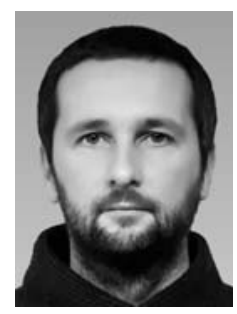

Assessment of activities of selected landslides in the Rożnowskie Dam Lake region based on field studies and analyses of differential digital models. Prz. Geol., 68: 60-68; doi: 10.7306/2020.2

A b s tr a c t. The article compares results of field assessment of activity of selected landslides in the Rożnowskie Lake region, obtained in 2010-2014 with a differential digital models (DDM) from airborne laser scanning data of 2010, 2013 and 2018. Results of DDM analyses were similar to those from field studies. The most difficult task in the field research was to distinguish between active landslides, where the last movements took place over three years after the date of landslide registration, and periodically active landslides, the last visible movements that took place five years ago. The article underlines that not all displacements within the landslides, visible on differential terrain models, are the result of colluvium landslide movement. Sometimes they are due to anthropogenic activities. Differential digital model in the Znamirowice landslide presents terrain changes that have resulted from intensive agricultural land use.

Keywords: Landslide activity, Digital Terrain Model, Differential Digital Model, Polish Outer Carpathians

Okolice Jeziora Rożnowskiego należą do obszarów silnie dotkniętych przez tzw. katastrofę osuwiskową, która wydarzyła się w Karpatach w maju 2010 r. w wyniku długotrwałych opadów deszczu. W samej gminie Gródek nad Dunajcem uległy wtedy zniszczeniu 53 budynki mieszkalne oraz wiele odcinków dróg gminnych, powiatowych, a także fragment drogi wojewódzkiej (Wykaz..., 2010). Podobne straty odnotowano również w gminie Łososina Dolna. Wiele uruchomionych wówczas osuwisk do dziś nie osiągnęło nowego stanu równowagi i nadal są aktywne.

W ostatnim stuleciu długotrwałe opady deszczu, skutkujące uaktywnieniem osuwisk, występowały w tym rejonie co najmniej 10-krotnie, w tym 7 razy między rokiem 1934 a 1974 (Bargielewicz, 1958; Wrzosek-Matl, 1961; Poprawa, 1969; Ziętara, 1974), a następnie w 1997 r. (Poprawa i in., 1997), w 2001 r. oraz w 2010 r. (m.in. Mrozek i in., 2012; Chowaniec i in., 2012; Wojciechowski i in., 2012a; Wójcik i in., 2017). O skali problemu osuwiskowego w rejonie Jeziora Rożnowskiego świadczą liczne opracowania poszczególnych osuwisk. Dotyczą one m.in. osuwiska w Gródku n. Dunajcem (Bargielewicz, 1958; Bober i in., 1997), osuwiska na górze Just (Chowaniec i in., 2012; Harba, Pilecki, 2015, 2017; Perski i in., 2015; Perski, 2019), osuwiska w Zbyszycach (Wojciechowski, 2007; Borkowski i in., 2011; Perski i in., 2011; Wojciechowski i in., 2012a, b), osuwiska w Kurowie (Wójcik i in., 2017), osuwiska w Zagórzu (Warmuz, Nescieruk, 2019), osuwiska w Piaskach-Dróżkowie (Perski i in., 2019) oraz osuwisk w Tęgoborzu, Rąbkowej, Bartkowej-Posadowej, Tropiu i Czchowie (Chowaniec i in., 2012).

Wraz z rozwojem badań wzrosła liczba oraz łączna powierzchnia rozpoznanych osuwisk. Według Ziętary (1974) w rejonie Jeziora Rożnowskiego osuwiska zajmują ok. 9\% powierzchni terenu. Według Bobera (1984) wskaźnik osuwiskowości powierzchniowej wynosi w tym rejonie $5,6 \%$, a w obszarze jednostki magurskiej - 16\%. Na podstawie Mapy Osuwisk i Terenów Zagrożonych Ruchami Masowymi w skali 1:10 000 (Bąk i in., 2011; Wójcik i in.,
2015) oraz badań własnych można przyjąć, że w rejonie tym osuwiska zajmują ok. $17 \%$ powierzchni terenu, a po odliczeniu płaskiej doliny Dunajca wynika, że prawie 20\% powierzchni stoków jest objętych ruchami masowymi.

W trakcie kartowania osuwiska jest określana jego aktywność. Zgodnie z instrukcją opracowania Mapy Osuwisk i Terenów Zagrożonych Ruchami Masowymi (MOTZ) (Grabowski i in., 2008) osuwisko jest aktywne wówczas, gdy przemieszczenia w jego obrębie zachodziły w okresie ostatnich 5 lat. Osuwiskiem okresowo aktywnym jest takie, na obszarze którego objawy aktywności występowały w przedziale czasowym 5-50 lat. Osuwisko nieaktywne to takie, którego aktywności nie zarejestrowano przez co najmniej 50 ostatnich lat.

Aktywność osuwisk określa się na podstawie obserwacji stanu zachowania form rzeźby wewnątrzosuwiskowej, m.in. śladów świeżych przemieszczeń i szczelin ekstensyjnych, a także w wyniku obserwacji zniszczeń infrastruktury i pozyskiwania informacji z literatury, kronik czy też od miejscowej ludności. W badaniach obszarów niezabudowanych, o nieznanej historycznej aktywności osuwiskowej, duże znaczenie ma doświadczenie osoby kartującej. Należy pamiętać, że stan zachowania form osuwiskowych jest zależny od sposobu użytkowania terenu oraz od litologii podłoża, na jakim rozwinęło się osuwisko. We fliszu cienkoławicowym z przewagą łupków rzeźba osuwiskowa może być bogata, ale podatna na zrównanie. Natomiast formy rzeźby osuwiska rozwiniętego w gruboławicowych piaskowcach mogą być wyraźne nawet po kilkudziesięciu latach, gdy jest ono już nieaktywne. Umowne granice czasowe, określone w instrukcji do MOTZ (Grabowski i in., 2008), oraz brak danych na temat historii osuwiska sprawiają, że w wielu przypadkach określenie jego aktywności zależy od subiektywnej oceny kartującego.

Celem badań było porównanie oceny aktywności kilku wybranych osuwisk w okolicy Jeziora Rożnowskiego na podstawie wyników badań terenowych, prowadzonych w latach 2010-2014, i wyników analiz różnicowych modeli terenu, wygenerowanych z chmur punktów uzyskanych w

\footnotetext{
${ }^{1}$ Państwowy Instytut Geologiczny - Państwowy Instytut Badawczy, ul. Skrzatów 1, 31-560 Kraków; mwod@pgi.gov.pl
} 
wyniku lotniczego skaningu laserowego w latach 2010, 2013 i 2018, oraz ocena przydatności obu tych metod do określania aktywności osuwisk.

\section{BUDOWA GEOLOGICZNA OBSZARU BADAŃ}

Do badań wybrano 5 osuwisk na Płaskowyżu Rożnowskim - dwa w Przydonicy, dwa w Lipiu oraz jedno w Znamirowicach (ryc. 1). Na płaskowyżu tym występuja równoleżnikowo wydłużone wzgórza o podobnej wysokości (ok. 400 m n.p.m.), obniżające się w kierunku doliny Dunajca (Starkel, 1972). Zostały one wyrzeźbione w utworach jednostki śląskiej Karpat fliszowych (ryc. 1). Najstarszymi skałami na obszarze badań są warstwy istebniańskie dolne i górne. Dolne piaskowce istebniańskie (wieku późny santon-kampan) często zawierają soczewki łupków. W górnych warstwach istebniańskich (wieku mastrycht-paleocen) wydziela się: dolne łupki istebniańskie, górne piaskowce istebniańskie oraz górne łupki istebniańskie. Powyżej nich zalegają średnio i gruboławicowe piaskowce ciężkowickie, tworzace dwa poziomy przeławicone pstrymi łupkami wieku późny paleocen-wczesny środkowy eocen (Leszczyński, Radomski, 1994; Cieszkowski, Waśkowska, 2010). Ponad gruboławicowymi piaskowcami zalega cienkoławicowy flisz warstw hieroglifowych: piaskowce i łupki z wkładkami łupków pstrych.

W rejonie badanych osuwisk występuje lokalne nasunięcie w obrębie jednostki śląskiej. Jest to nasunięcie Przy- donicy (Paul, 2001), w którym warstwy hieroglifowe kontaktują z łupkami wczesnooligoceńskich warstw menilitowych (Burtan i in., 1991). Do najmłodszych utworów fliszowych jednostki śląskiej na obszarze badań należą piaskowce i łupki warstw krośnieńskich dolnych. Na południowy zachód od badanych osuwisk na jednostkę śląską nasunęły się piaskowce i łupki warstw krośnieńskich, zaliczane do strefy Michalczowej (Cieszkowski, 1992). W skałach tych występują liczne uskoki (ryc. 1), które - podobnie jak nasunięcia - mogły mieć duży wpływ na rozwój osuwisk na płaskowyżu.

\section{METODYKA BADAŃ}

Do analizy porównawczej posłużyły dane pochodzące z Mapy Osuwisk i Terenów Zagrożonych Ruchami Masowymi w skali 1:10 $000-\mathrm{z}$ obszaru gminy Gródek nad Dunajcem (Wójcik i in., 2015) oraz gminy Łososina Dolna (Bąk i in., 2011). Wykorzystano również informacje z kart rejestracyjnych osuwisk (KRO) zinwentaryzowanych w tych gminach. W 2019 r. przeprowadzono terenowe obserwacje osuwisk. Wyniki dotychczasowych badań dotyczących aktywności osuwisk porównano z różnicowymi modelami terenu. Model różnicowy uzyskuje się poprzez zestawienie danych z co najmniej dwóch nalotów lotniczego skaningu laserowego (ALS - Airborne Laser Scanning), wykonanych na tym samym terenie w różnym czasie (Borkowski i in., 2012; Borkowski, 2015; Perski, Wojciechowski, 2015).

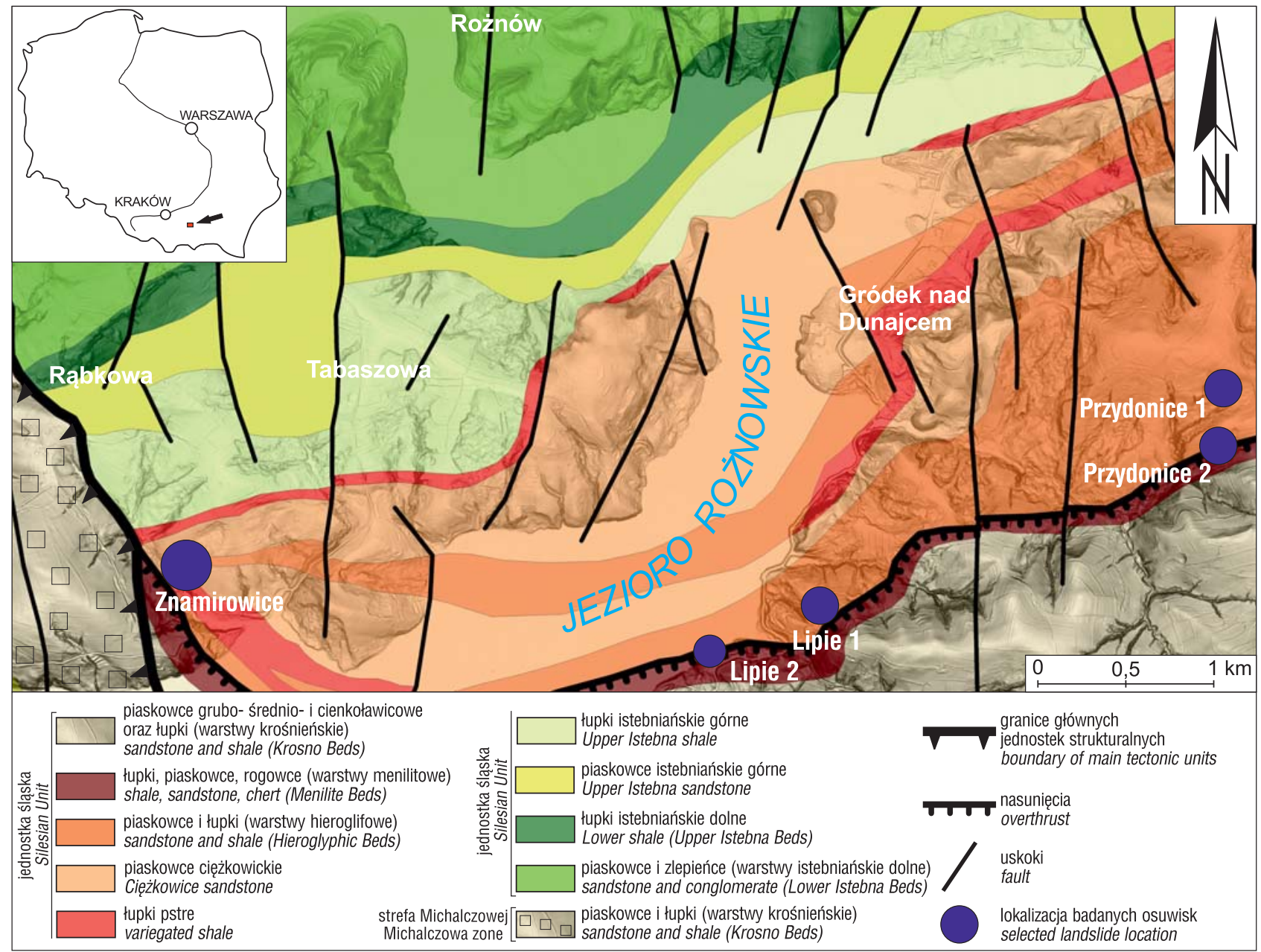

Ryc. 1. Lokalizacja badanych osuwisk na tle uproszczonej mapy geologicznej (wg Burtan i in., 1991; Cieszkowski i in., 1987; zmieniona) Fig. 1. Location of studied landslides on the geological map (after Burtan et al., 1991; Cieszkowski et al., 1987; modified) 
Przedstawia on różnice wysokościowe między numerycznym modelem terenu (NMT) uzyskanym w wyniku młodszego nalotu a NMT wygenerowanym na podstawie danych ze starszego nalotu. Jeśli w tym czasie nastąpiło obniżenie terenu lub powstała skarpa, różnica jest ujemna. Natomiast wypiętrzenie terenu na skutek akumulacji koluwium czy też wypchnięcia materiału skalnego przemieszczanego po wklęsłocylindrycznej (szuflowej) powierzchni poślizgu daje wynik dodatni (ryc. 2).

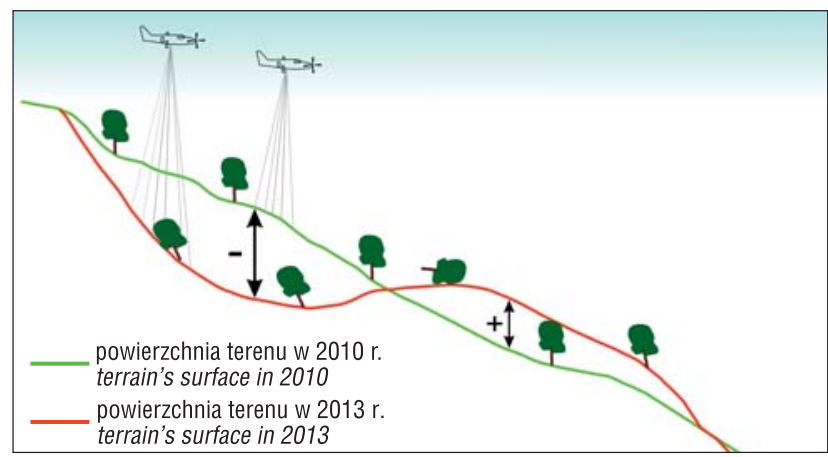

Ryc. 2. Schemat tworzenia modeli różnicowych

Fig. 2. Differential digital model creation scheme

Do badań wykorzystano NMT sprzed katastrofy osuwiskowej, wykonany na zlecenie Uniwersytetu Przyrodniczego we Wrocławiu na podstawie danych ALS z kwietnia 2010 r. (Borkowski i in., 2011; Wojciechowski i in., 2012a), NMT z roku 2013 (dane projektu ISOK) oraz NMT z roku 2018 (dane ALS uzyskane na zlecenie PIG-PIB). Ze względu na różnice $\mathrm{w}$ odfiltrowaniu danych wejściowych $\mathrm{z}$ różnych lat przemieszczenia zobrazowane na modelach różnicowych pomierzono z dokładnością do $35 \mathrm{~cm}$.

Karty rejestracyjne analizowanych osuwisk wykonano w latach 2010-2014, w związku z tym modele różnicowe $z$ lat 2010, 2013 i 2018 uznano za dobry materiał porównawczy, przydatny do weryfikacji terenowej oceny aktywności osuwisk, udokumentowanej na KRO.

\section{WYNIKI BADAŃ}

\section{Osuwisko w Przydonicy 1}

Osuwisko w Przydonicy 1 znajduje się w zachodniej części miejscowości, na niezabudowanym obszarze leśnym (patrz ryc. 3 na str. 71), i obejmuje powierzchnię 6,6 ha (ryc. 1). Rozpoczyna się ono wyraźna, stromą $\left(45^{\circ}\right)$ skarpą główną, której wysokość waha się od $0,5 \mathrm{~m}$ w części wschodniej do $6,5 \mathrm{~m}$ w części środkowej. W części zachodniej skarpa jest mniej wyraźna, a jej nachylenie maleje do $20^{\circ}$. Poniżej skarpy występują liczne nabrzmienia gruntu są to progi akumulacyjne przemieszczonego koluwium. Największy próg ma wysokość ok. $5 \mathrm{~m}$. Pomiędzy nabrzmieniami są widoczne zagłębienia terenu. Część z nich jest bezodpływowa i podmokła - charakterystyczna dla obszarów osuwiskowych. W zachodniej części osuwiska jego rzeźba jest znacznie mniej wyraźna, być może na skutek aktywnej działalności rolniczej. Jednak i tu, mimo zmian antropogenicznych, poniżej stosunkowo połogiej skarpy są widoczne niewielkie nierówności, wskazujące na ruch koluwium. Czoło osuwiska najlepiej się zaznacza w środkowej części jęzora.

W niskiej i stosunkowo świeżej skarpie wschodniej odsłaniają się lessy. Poza lessami w obrębie osuwiska wystę- puje rumosz piaskowców cienkoławicowych i łupków należących do warstw hieroglifowych. Według autorów arkusza Ciężkowice SMGP 1 : 50000 (Cieszkowski i in., 1987) utwory te zapadają konsekwentnie względem przemieszczeń grawitacyjnych, zatem osuwisko jest najprawdopodobniej zsuwem strukturalnym (Kleczkowski, 1955; Bober, 1984; Dikau i in., 1996; Margielewski, 2009), który wykorzystuje powierzchnię uławicenia jako płaszczyznę poślizgu, a efektem akumulacji materiału koluwialnego są wydłużone, poprzeczne progi akumulacyjne. Biorąc pod uwage obszar osuwiska, wysokość skarpy oraz wymiary form rzeźby wewnątrzosuwiskowej można przypuszczać, że powierzchnia poślizgu znajduje się poniżej 10 m p.p.t.

$\mathrm{Na}$ podstawie analizy różnicowych modeli terenu stwierdzono aktywność środkowej części osuwiska w latach 2010-2013. Model różnicowy między rokiem 2013 a 2018 nie ukazał natomiast istotnych przemieszczeń, które mogłyby być następstwem ponownego uaktywnienia osuwiska. W 2010 r. obniżenia terenu pod skarpą główną i skarpami wtórnymi sięgały do $1,5 \mathrm{~m}$, a wypiętrzenia $\mathrm{w}$ rejonie czoła osuwiska dochodziły do $2 \mathrm{~m}$ (ryc. 4). Zmiany te nastapiły najprawdopodobniej na skutek katastrofalnych opadów deszczu w maju 2010 r. W zachodniej części osuwiska przemieszczenia były znikome i mieściły się w granicy błędu (tj. $35 \mathrm{~cm})$. Analizy modeli wskazały również, że największy z progów akumulacyjnych jest wynikiem starych przemieszczeń sprzed 2010 r. Podczas prac terenowych, przeprowadzonych z końcem 2013 r., środkowo-wschodnią część osuwiska określono jako okresowo aktywną, a zachodnią jako nieaktywną (ryc. 4).

\section{Osuwisko w Przydonicy 2}

Osuwisko w Przydonicy 2 rozwinęło się w obrębie leja źródłowego potoku Zbęk i obejmuje powierzchnię 2,6 ha. Rozpoczyna się ono skarpą wysokości od $0,5 \mathrm{~m}$ do $2 \mathrm{~m}$, o nachyleniu od $25^{\circ}$ do $50^{\circ}$, i w całości znajduje się na terenie leśnym. W środkowej i zachodniej części główna skarpa osuwiskowa ma przebieg prostolinijny. Poniżej występują półkoliste skarpy wtórne. Powierzchnia terenu w obrębie osuwiska jest mocno pofałdowana, szczególnie poniżej skarp wtórnych. Czoło osuwiska jest dobrze zachowane jedynie w środkowej części, gdzie ma wysokość $3 \mathrm{~m}$.

W skarpie głównej odsłaniają się zapiaszczone lessy. W skarpach wtórnych są widoczne fragmenty piaskowców cienkoławicowych i łupków warstw hieroglifowych. Osuwisko znajduje się w strefie lokalnego nasunięcia Przydonicy (Paul, 2001), gdzie warstwy hieroglifowe kontaktuja z łupkami menilitowymi (ryc. 1). Na podstawie morfometrii osuwiska i form wewnątrzosuwiskowych można wnioskować, że maksymalna miąższość koluwium wynosi ok. $10 \mathrm{~m}$.

Osuwisko w Przydonicy 2 powstało w wyniku zsuwu złożonego. W północno-zachodniej części osuwiska, poniżej prostolinijnych skarp można je określić jako strukturalne (translacyjne), o kierunku przemieszczeń zgodnym $\mathrm{z}$ nachyleniem warstw, natomiast $\mathrm{w}$ pozostałej części zachodziły przemieszczenia różnego typu, m.in. rotacyjne. Na podstawie analiz różnicowych modeli terenu stwierdzono, że forma ta rozwijała się od dołu w górę stoku (osuwisko delapsywne). Charakterystyczne, prostolinijne skarpy utworzyły się wtórnie wskutek długotrwałych opadów w $2010 \mathrm{r}$. (patrz ryc. 5 na str. 71), powodując przemieszczenie i obniżenie płata osuwiskowego - miejscami o ponad $1,5 \mathrm{~m}$ (ryc. 6). Wypiętrzenia terenu na skutek akumulacji koluwium w środkowej i dolnej części osuwiska przekraczały 


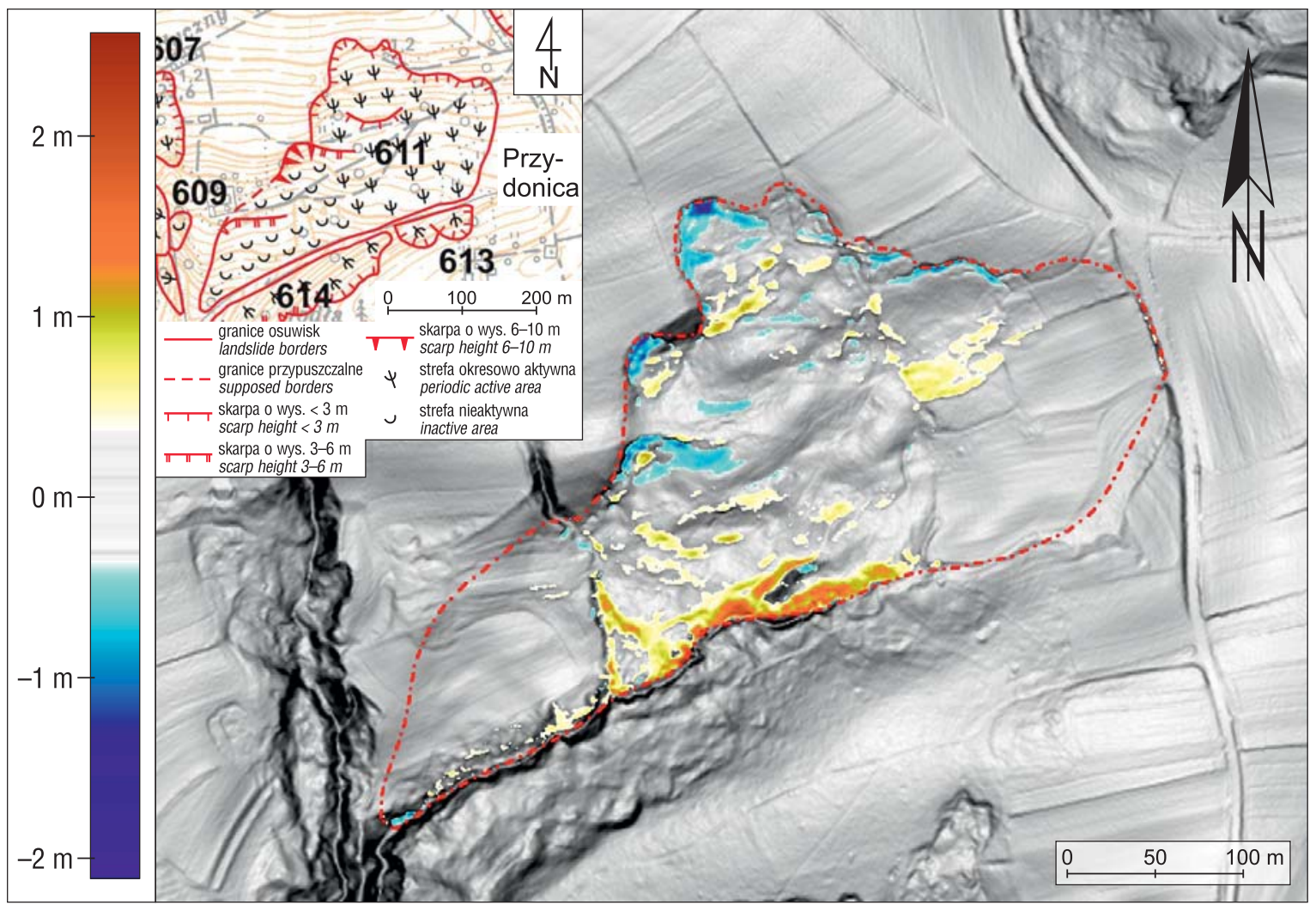

Ryc. 4. Model różnicowy osuwiska w Przydonicy 1 (2010-2013) oraz fragment mapy osuwisk gminy Gródek nad Dunajcem (Wójcik i in., 2015)

Fig. 4. Differential digital model of the landslide in Przydonica 1 (2010-2013) and a part of landslide map in the Gródek nad Dunajcem community (Wójcik et al., 2015)

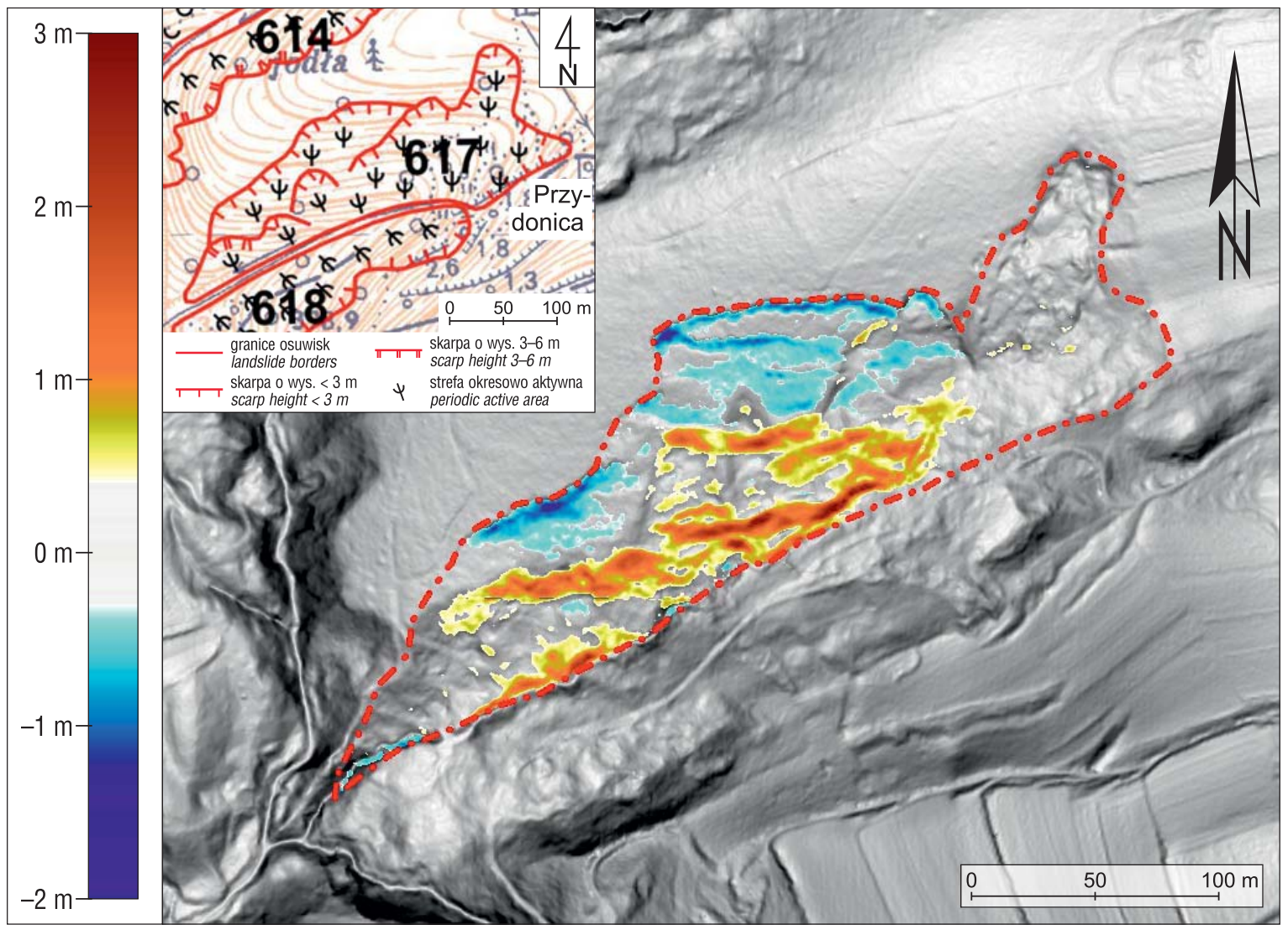

Ryc. 6. Model różnicowy osuwiska w Przydonicy 2 (2010-2013) oraz fragment mapy osuwisk gminy Gródek nad Dunajcem (Wójcik i in., 2015)

Fig. 6. Differential digital model (DDM) of the landslide in Przydonica 2 (2010-2013) and a part of landslide map in the Gródek nad Dunajcem community (Wójcik et al., 2015) 
miejscami 2,5 m. Przemieszczenia pionowe we wschodniej części osuwiska były nieznaczne i mieściły się w granicy błędu $(35 \mathrm{~cm})$.

Na różnicowym modelu terenu między rokiem 2013 a 2018 nie zaznaczyły się większe przemieszczenia, zatem obecnie osuwisko to można uznać za okresowo aktywne. W wyniku prac terenowych przeprowadzonych z końcem 2013 r. (czyli w końcowym okresie ciągłej aktywności) całe osuwisko uznano za okresowo aktywne (ryc. 6).

\section{Osuwisko w Lipiu 1}

Osuwisko w Lipiu 1 rozwinęło się na obszarze leja źródłowego i obejmuje powierzchnię 3,6 ha. Obszar osuwiska, w przeciwieństwie do poprzednich, jest zabudowany znajduje się na nim pojedyncza zabudowa oraz droga gminna. Główna skarpa osuwiska powstała w gruboławicowych piaskowcach warstw krośnieńskich, odpornych na denudację i w południowej części osiąga wysokość $15 \mathrm{~m}$. Przemieszczenia nastapiły $\mathrm{w}$ cienkoławicowych piaskowcach i łupkach warstw hieroglifowych. Górna część obszaru osuwiska jest użytkowana rolniczo, przez co rzeźba osuwiskowa poniżej skarpy została cześciowo zrównana. Na skutek reaktywacji formy w czerwcu 2010 r. w środkowej partii osuwiska rozwinęły się skarpy wtórne o wysokości 3-4 m, ruchy te przyczyniły się do zniszczenia drogi gminnej oraz uszkodzenia 4 budynków (Wójcik, Perski, 2010). Nad skarpą wtórną stwierdzono szczeliny, wskazujące na ciagłą aktywność w górnej części osuwiska. Poniżej nowo powstałych skarp występują liczne nabrzmienia i zagłębienia terenu. Osuwisko jest efektem zsuwu złożonego o przemieszczeniach insekwentnych w stosunku do położenia warstw. Podczas wizji terenowej w 2010 r. wyznaczono dwie strefy aktywności, które można bezpośrednio korelować z wynikami analiz różnicowych modeli terenu (ryc. 7). Pionowe obniżenia terenu w północno-zachodniej części osuwiska, utworzone między rokiem 2010 a 2013, miejscami osiagały ponad $2 \mathrm{~m}$, podobnego rzędu były wypiętrzenia obserwowane na tym obszarze. Na NMT z lat 2013-2018 nie zarejestrowano pionowych przemieszczeń powierzchni gruntu, które przekraczałyby $35 \mathrm{~cm}$.

\section{Osuwisko w Lipiu 2}

Osuwisko w Lipiu 2 rozwinęło się na zboczu nachylonym w kierunku Jeziora Rożnowskiego (ryc. 1). Obejmuje ono tylko 0,5 ha obszaru leśnego, ale w przyszłości może stanowić zagrożenie dla drogi wojewódzkiej nr 975. Główna skarpa osuwiska jest półkolista i wyraźna. W południowej części osiaga wysokość $18 \mathrm{~m}$ i zapada pod kątem $45^{\circ}$, po czym przechodzi w wyraźne i strome skarpy boczne, zaznaczające się również w dolnej części osuwiska. Poniżej skarpy głównej znajduje się wypłaszczenie z licznymi zagłębieniami i nabrzmieniami, będące świadectwem niedawnych przemieszczeń. Większość pni drzew porastających jęzor osuwiska jest poskręcana i przechylona. Osuwisko kończy się wyraźnym czołem o wysokości 4,5 m, którego część znajduje się zapewne pod powierzchnią wody jeziora. Prawdopodobnie ma ono formę zsuwu rotacyjnego o cylindrycznym kształcie powierzchni poślizgu (Varnes, 1978; Dikau i in., 1996), a wypiętrzenie gruntu w rejonie czoła (ryc. 8) jest związane z wypchnięciem i przemieszczeniem mas skalnych po tej powierzchni. Ze względu na układ warstw podłoża jest to osuwisko obsekwentne.

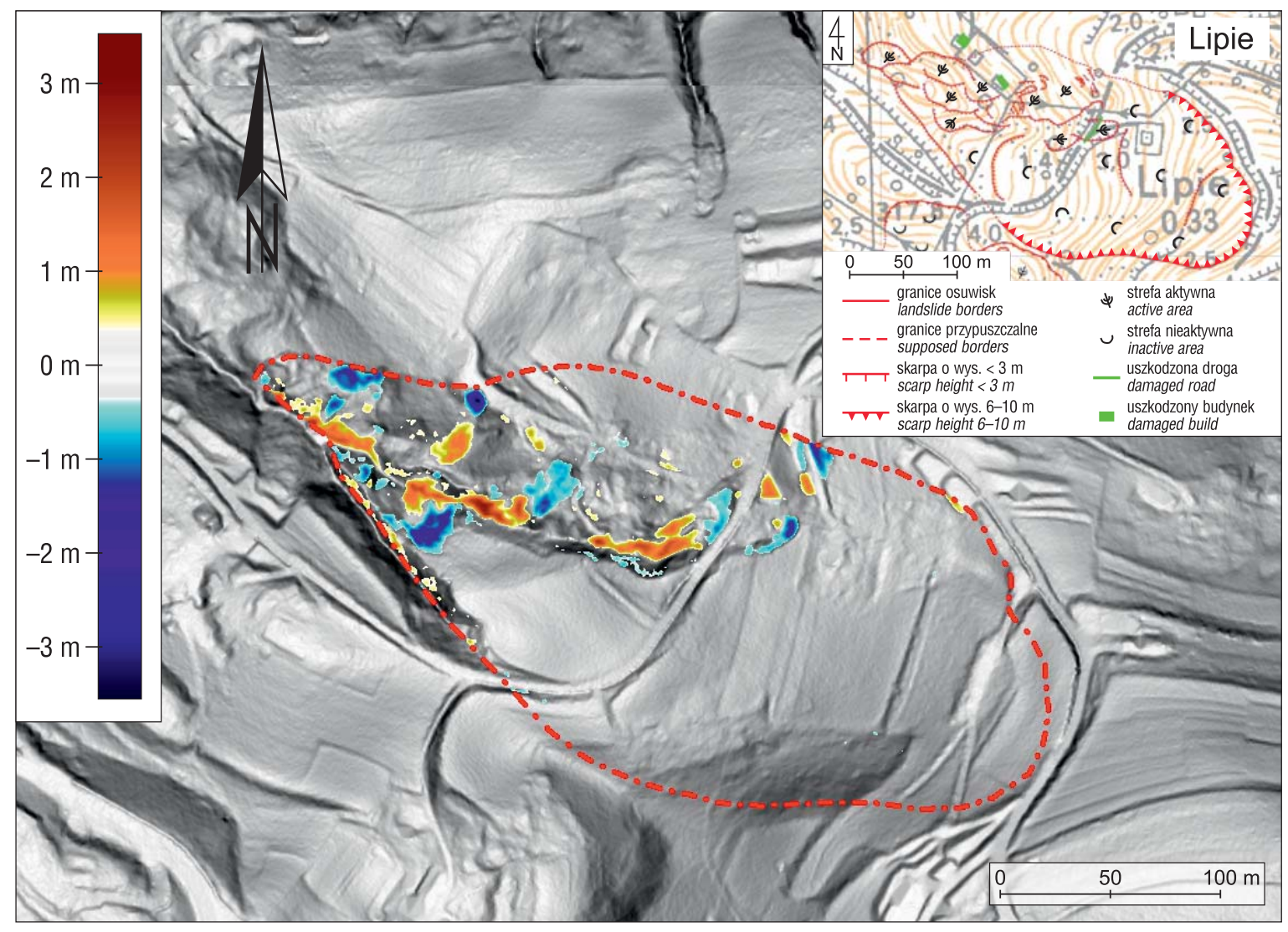

Ryc . 7. Model różnicowy osuwiska w Lipiu 1 (2010-2013) i rycina z karty dokumentacyjnej osuwiska (Wójcik, Perski, 2010) Fig. 7. DDM of the landslide in Lipie 1 (2010-2013) and a sketch from the landslide documentation card (Wójcik, Perski, 2010) 
Miąższość koluwium, mimo stosunkowo niewielkich rozmiarów osuwiska, może miejscami przekraczać $10 \mathrm{~m}$.

Osuwisko w Lipiu 2 rozwinęło się w warstwach hieroglifowych i leżących na nich łupkach menilitowych (ryc. 1). Podczas prac terenowych w 2014 r. stwierdzono ciągłą aktywność osuwiska, co potwierdziły również wyniki analiz różnicowych modeli terenu (ryc. 8). Między rokiem 2010 a 2013 doszło do obniżenia terenu o ok. 2,5 m w rejonie skarpy głównej oraz wypiętrzenia gruntu o ok. $3 \mathrm{~m}$ w rejonie czoła. Różnicowy model terenu między rokiem 2013 a 2018 ukazał tylko niewielkie obniżenia (do 0,5 m), głównie w rejonie czoła osuwiska, prawdopodobnie związane z jego erozją przez wody Jeziora Rożnowskiego.

\section{Osuwisko w Znamirowicach}

Rozległe osuwisko w Znamirowicach, obejmujące powierzchnię 7,2 ha, znajduje się poza obszarem nalotu ALS z kwietnia 2010 r. Rozpoczyna się ono w środkowej części stoku skarpą główną o wysokości $5 \mathrm{~m}$ i nachyleniu od $20^{\circ}$ do $38^{\circ}$. Skarpa najlepiej zachowała się po stronie północnej i północno-zachodniej. W górnej części została przekształcona przez nasyp budowlany. Poniżej skarpy występują wielkoskalowe zagłębienia i nabrzmienia gruntu w formie muld charakterystycznych dla osuwisk rozwiniętych w utworach ilastych (Wódka, 2019), dobrze widoczne ze względu na brak zarośli. Progi akumulacyjne osiagają wysokość $3 \mathrm{~m}$. Niedawne deformacje terenu, związane z ciagła aktywnością osuwiska, są dobrze widoczne szczególnie w dolnej, południowo-zachodniej części stoku. Osuwisko to rozwinęło się w piaskowcach ciężkowickich i przedzielających je łupkach pstrych oraz łupkach hieroglifowych. Nie bez znaczenia jest też fakt, że jest ono usytuowane w sąsiedztwie nasunięcia jednostki Michalczowej na jednostkę śląską. Morfologia osuwiska oraz duży udział łupków ilastych w koluwium wskazują, mimo braku pomiarów położenia warstw, na dominację przemieszczeń rotacyjnych (Margielewski, 2004), które następowały insekwentnie $\mathrm{w}$ stosunku do orientacji warstw w sąsiedztwie osuwiska. Biorąc pod uwagę rozmiar całej formy, wysokość skarp i progów akumulacyjnych, można przyjąć, że miąższość koluwium osiąga $20 \mathrm{~m}$.

Osuwisko w Znamirowicach uaktywniło się 19.05.2010 r., uszkadzając drogę gminna, drogę dojazdową do gospodarstwa oraz 2 budynki gospodarcze (Wójcik i in., 2010). Podczas wizji terenowej w 2010 r. zarejestrowano bogata rzeźbę wewnątrzosuwiskową: skarpy wtórne, szczeliny, progi oraz jeziorka i całe osuwisko uznano za aktywne. Wysokość progów akumulacyjnych dochodziła wtedy do $7 \mathrm{~m}$. Dziś rzeźba osuwiskowa jest znacznie mniej wyraźna i niejednoznaczna. Analizy numerycznego modelu terenu z 2013 r. potwierdzają mnogość form wewnątrzosuwiskowych, które utworzyły się po uaktywnieniu w 2010 r. Brak danych ALS sprzed katastrofy osuwiskowej nie pozwala określić wielkości przemieszczeń, jakie zaszły w jej trakcie. Intensywne przemieszczenia pionowe są natomiast widoczne na różnicowym modelu terenu z roku 2013 i 2018 (ryc. 9). Obniżenia w wielu miejscach dochodzą do $2 \mathrm{~m}$, a wypiętrzenia, szczególnie w środkowej i dolnej części osuwiska, przekraczają 1,5 m. Większość przemieszczeń z tego okresu nie jest jednak wynikiem ruchu koluwium, lecz niwelacji rzeźby osuwiskowej na skutek działalności rolniczej, co utrudnia ocenę intensyfikacji ruchów osuwiskowych na podstawie modelu różnicowego. Z analiz NMT z 2013 r. oraz NMT z 2018 r. wynika, że liczne zagłębienia osuwiskowe zostały zasypane, a progi akumulacyjne zrównane (ryc. 9). W tym przypadku ciagłą aktywność osuwiska potwierdziły jedynie obserwacje terenowe, podczas których udokumentowano obecność świeżych skarp i szczelin, najlepiej widocznych w dolnej części osuwiska.

\section{DYSKUSJA}

Wyniki terenowej oceny aktywności osuwisk są bardzo zbliżone do uzyskanych w trakcie obserwacji różnicowych modeli terenu. Rozbieżności dotyczą głównie kwestii odróżniania aktywnych stref osuwiskowych od okresowo aktywnych. Z przeprowadzonej analizy porównawczej wynika, że podczas terenowej oceny aktywności osuwisk najwięcej trudności sprawia odróżnienie „starego” aktywnego osuwiska, na którym ostatnie objawy aktywności wystąpiły 3-5 lat temu, a świeże formy, takie jak szczeliny, mogły już zostać zatarte, od „,młodego” osuwiska okresowo aktywnego, objawiającego aktywność w ciagu ostatnich 5-10 lat. Tak było w przypadku osuwisk w Przydonicy. Osuwiska te były kartowane 3-4 lata po ich uaktywnieniu i zostały uznane za okresowo aktywne, podczas gdy wyniki analiz różnicowych modeli terenu wskazały na ich ciągła aktywność w tym czasie. Nie stwierdzono natomiast ich 


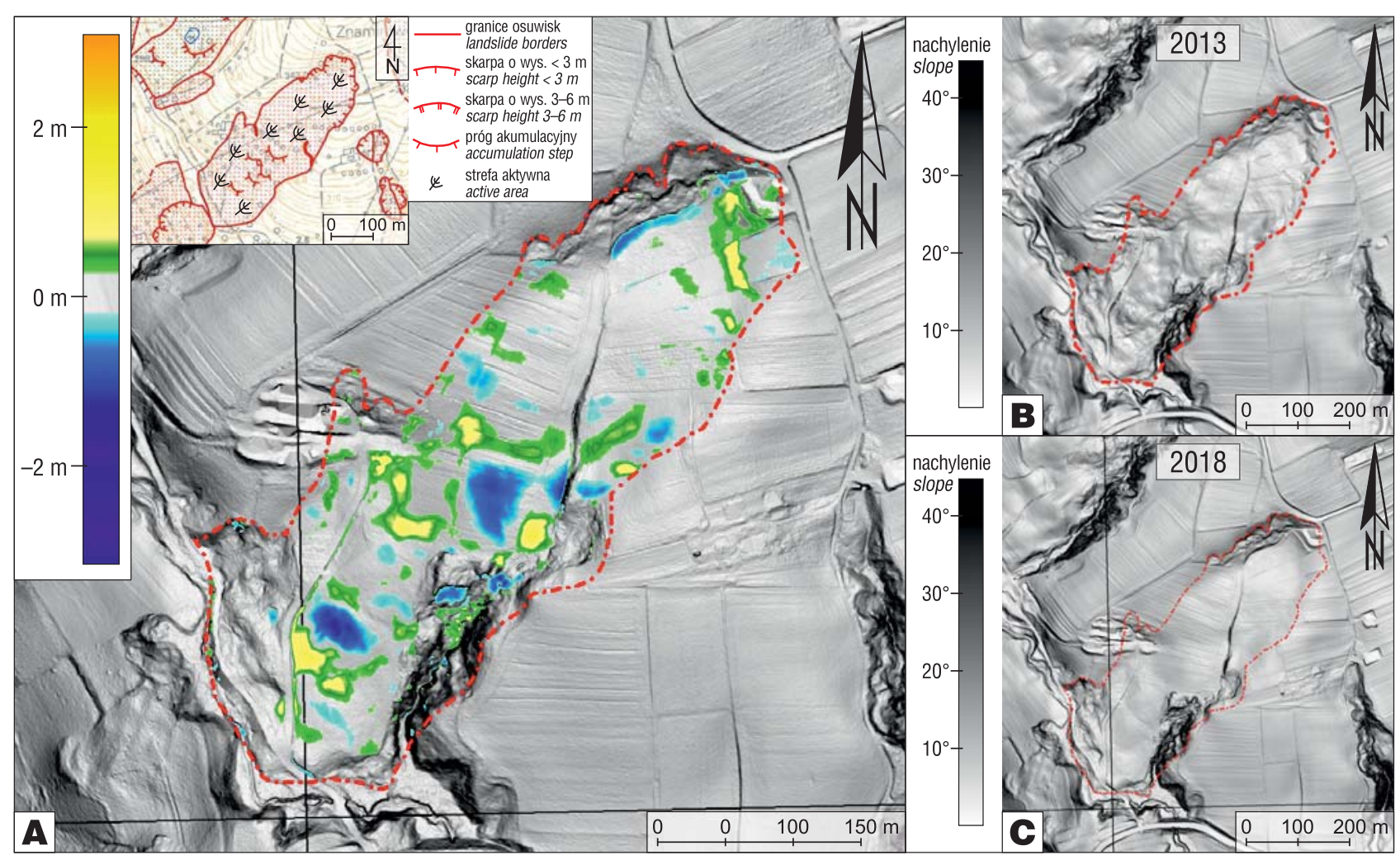

Ryc. 9. Modele osuwiska w Znamirowicach, obrazujące pionowe przemieszczenia gruntu w latach 2013-2018, powstałe w wyniku intensywnego rolniczego użytkowania terenu: A - model różnicowy i fragment mapy osuwisk w gminie Łososina Dolna (Bąk i in., 2011); B - numeryczny model terenu z 2013 r.; C - numeryczny model terenu z 2018 r.

Fig. 9. Models of landslides in Znamierowice, illustrating vertical displacements since 2013 to 2018, resulting from intensive agricultural use of this area: A - differential digital model and a part of landslide map in the Łososina Dolna community (Bąk et al., 2011); B digital terrain model from 2013; C - digital terrain model from 2018

aktywności po 2013 r., zatem obecnie należą one do osuwisk okresowo aktywnych.

W toku badań terenowych najtrafniej określano aktywne strefy osuwiskowe, które były niedawno odmładzane. Dobrym przykładem są tu wyniki terenowych badań osuwiska w Lipiu 1, w trakcie których dość dokładnie wyznaczono w jego obrębie strefę aktywną i nieaktywną, na co wskazują wyniki analizy różnicowej (ryc. 7). Należy podkreślić, że w badaniach tych uwzględniono stan zachowania infrastruktury występującej na obszarze osuwiska, a poczynione obserwacje uszkodzeń drogi oraz pęknięć w ścianach budynków ułatwiły zaklasyfikowanie jego części do obszarów aktywnych osuwiskowo.

Wyniki badań osuwiska w Znamirowicach dowiodły, że przemieszczenia widoczne na różnicowym modelu terenu nie zawsze są związane $\mathrm{z}$ ruchami masowymi. W tym przypadku zmiany wysokościowe między 2013 a 2018 r. spowodowała intensywna działalność rolnicza, która przyczyniła się do niwelacji rzeźby osuwiskowej. Osuwisko w Znamirowicach może służyć jako modelowy przykład szybkiego zacierania rzeźby aktywnego osuwiska, ukazujący duże znaczenie badań terenowych w ocenie aktywności osuwisk. Czasem zdarza się, że na podstawie obserwacji NMT czy modeli różnicowych nie jest możliwe stwierdzenie niewielkich szczelin czy śladów świeżych przemieszczeń, świadczących o aktywności strefy osuwiskowej. Zmiany wysokościowe w obrębie osuwisk, odczytywane $\mathrm{z}$ różnicowych modeli terenu, mogą być też wynikiem wykonywania nasypów lub wkopów budowlanych, te jednak, ze względu na kształt, są stosunkowo łatwe do rozpoznania.
Dostęp do danych ALS z różnych lat umożliwia śledzenie zmian intensywności przemieszczeń w czasie i korelowanie ich z różnymi czynnikami wpływającymi na rozwój ruchów masowych.

Opisane osuwiska rozwinęły się na podobnym podłożu litologicznym, w obrębie drobnorytmicznego fliszu karpackieco (warstw hieroglifowych, warstw menilitowych i łupków pstrych). W latach 2010-2013 wszystkie uaktywniły się - przynajmniej częściowo. Dodatkowym czynnikiem, odgrywającym dużą rolę w ich rozwoju, jest osłabienie górotworu przez nasunięcie Przydonicy (ryc. 1).

\section{WNIOSKI}

Ocena aktywności osuwisk przeprowadzana w ramach badań terenowych jest zazwyczaj subiektywna, zwłaszcza na terenach nieużytkowanych przez człowieka. Najtrudniej jest odróżnić osuwisko aktywne od okresowo aktywnego, gdy ostatnie przemieszczenia wystapiły 3-8 lat temu. Dobrym narzędziem do obiektywnej oceny aktywności osuwisk są natomiast różnicowe modele terenu, lecz i one w przypadku niewielkich przemieszczeń mogą okazać się niewystarczające. W rejonie Jeziora Rożnowskiego modele te najlepiej sprawdziły się do analiz przemieszczeń po katastrofie osuwiskowej w 2010 r.

W trakcie analiz różnicowych modeli terenu należy mieć na uwadze wszelkie zmiany terenu będące wynikiem działalności człowieka, m.in. niwelację form osuwiskowych na skutek rolniczego użytkowania terenu, która może być przyczyną błędnego interpretowania obrazów różnicowych. 
Na obszarach o wysokim współczynniku osuwiskowości oraz dużym ryzyku osuwiskowym warto prowadzić lotniczy skaning laserowy w stałych odstępach czasu niezależnie od wystąpienia zjawisk katastrofalnych. Wyniki obserwacji umożliwiłyby śledzenie zmian dynamiki przemieszczeń, ostrzeganie o zagrożeniu oraz ułatwiłyby wskazanie przyczyn rozwoju osuwisk na danym obszarze.

Badania sfinansowano $\mathrm{z}$ tematu PIG-PIB 61.3506.1703.00.0.

\section{LITERATURA}

BARGIELEWICZ B. 1958 - Osuwisko w Kobyle-Gródku nad Jeziorem Rożnowskim. Kwart. Geol., 2 (2): 420-443.

BAK M., DŁUGOSZ M., GORCZYCA E., KASINA K., KOZIOŁ T., WROŃSKA-WAŁACH D., WYDERSKI P. 2011 - Mapa osuwisk i terenów zagrożonych ruchami masowymi skala 1:10 000, gmina Łososina Dolna, pow. nowosadecki, woj. małopolskie. NAG PIG-PIB, Warszawa. BOBER L. 1984 - Rejony osuwiskowe w polskich Karpatach fliszowych ich związek z budową geologiczną regionu. Biul. Inst. Geol., 340: 115-158. BOBER L., THIEL K., ZABUSKI L. 1997 - Zjawiska osuwiskowe w Polskich Karpatach fliszowych. Geologiczno-inżynierskie właściwości wybranych osuwisk. IBW PAN.

BORKOWSKI A. 2015 - Numeryczne modele wysokościowe i produkty pochodne. [W:] Wężyk P. (red.), Podręcznik dla uczestników szkoleń Z wykorzystania produktów LiDAR. GUGiK, Warszawa: 110-131.

BORKOWSKI A., PERSKI Z., WOJCIECHOWSKI T., JÓžKÓW G., WÓJCIK A. 2011 - Landslides mapping in Roznow lake vicinity, Poland using airborne laser scanning data. Acta Geodynam. Geomater., 8, 3(163): 325-333.

BORKOWSKI A., PERSKI Z., WOJCIECHOWSKI T., WÓJCIK A. 2012 - LiDAR and SAR Data Application for Landslide Study In Carpathians Region (Southern Poland). Proceedings of the XXII Congress of the International Society of Photogrammetry and Remote Sensing. Melbourne, 25 August - 1 September 2012.

BURTAN J., CIESZKOWSKI M., ŚLACZKA A., ZUCHIEWICZ W. 1991 - Szczegółowa Mapa Geologiczna Polski w skali 1:50 000, arkusz Męcina (1018). NAG PIG-PIB, Warszawa.

CIESZKOWSKI M. 1992 - Strefa Michalczowej - nowa jednostka strefy przedmagurskiej w Zachodnich Karpatach Fliszowych i jej geologiczne otoczenie. Wyd. AGH, Kraków: 125.

CIESZKOWSKI M., WAŚKOWSKA A. 2010 - Zamki znad jezior Rożnowskiego i Czchowskiego jako geoturystyczne lapidaria i rola piaskowców istebniańskich w ich powstaniu. Geoturystyka, 2 (21): 3-18. CIESZKOWSKI M., KOSZARSKI A., LESZCZYNSKI S., MICHALIK K., RADOMSKI A., SZULC J. 1987 - Szczegółowa Mapa Geologiczna Polski w skali 1:50 000, arkusz Cieżkowice (1019). Wyd. Geol., Warszawa. CHOWANIEC J. (red.), WÓJCIK A. (red.), MROZEK T., RĄCZKOWSKI W., NESCIERUK P., PERSKI Z., WOJCIECHOWSKI T., MARCINIEC P, ZIMNAL Z., GRANOSZEWSKI W. 2012 - Osuwiska w województwie małopolskim. Atlas - przewodnik. Departament Środowiska, Rolnictwa i Geodezji Urzędu Marszałkowskiego Województwa Małopolskiego, Zespół Geologii, Kraków.

DIKAU R., BRUNSDEN D., SCHROTT L., IBSEN M. L. (red.) $1996-$ Landslide recognition. Identification, Movement and Causes. J. Willey \& Sons: 251

GRABOWSKI D., MARCINIEC P., MROZEK T., NESCIERUK P., RACZKOWSKI W., WÓJCIK A., ZIMNAL Z. 2008 -Instrukcja opracowania mapy osuwisk i terenów zagrożonych ruchami masowymi, Państw. Inst. Geol.

HARBA P., PILECKI Z. 2015 - Czasoprzestrzenna analiza ruchu osuwiskowego metodą interferometrii sejsmicznej na przykładzie osuwiska Tęgoborze-Just. Ogólnopolska Konferencja O!suwisko 19-22 maja 2015, Wieliczka. Mat. konf.: 25-26.

HARBA P., PILECKI Z. 2017 - Assessment of time-spatial changes of shear wave velocities of flysch formation prone to mass movements by seismic interferometry with the use of ambient noise. Landslides 14 : $1225-1233$.

KLECZKOWSKI A. 1955 - Osuwiska i zjawiska pokrewne. Wyd. Geol. Warszawa: 93.

LESZCZYŃSKI S., RADOMSKI A. 1994 - Objaśnienia do Szczegółowej Mapy Geologicznej Polski 1:50000, arkusz Ciężkowice (1019). NAG PIG-PIB, Warszawa.

MARGIELEWSKI W. 2004 - Typy przemieszczeń grawitacyjnych mas skalnych w obrębie form osuwiskowych polskich Karpat fliszowych. Prz. Geol., 52 (7): 603-614.
MARGIELEWSKI W. 2009 - Problematyka osuwisk strukturalnych w Karpatach fliszowych w świetle zunifikowanych kryteriów klasyfikacji ruchów masowych - przegląd krytyczny. Prz. Geol., 57 (10): 905-917. MROZEK T., RĄCZKOWSKI W., WÓJCIK A. 2012 -Zdarzenie osuwiskowe 2010 w świetle dotychczasowej rejestracji osuwisk. II Polski Kongres Geologiczny, 17-19 września 2012 r., Warszawa: 61-62.

PAUL Z. 2001 - Szczegółowa Mapa Geologiczna Polski w skali 1:50000, arkusz Męcina. NAG PIG-PIB, Warszawa.

PERSKI Z. 2019 - Zaawansowane techniki InSAR w monitorowaniu osuwisk. Prz. Geol., 67 (5): 351-359.

PERSKI Z., WOJCIECHOWSKI T. 2015 - Monitorowanie ruchów masowych (osuwiska, spływy, zerwy). [W:] Wężyk P. (red.), Podręcznik dla uczestników szkoleń z wykorzystania produktów LiDAR. GUGiK, Warszawa: $168-172$.

PERSKI Z., BORKOWSKI A., WOJCIECHOWSKI T., WÓJCIK A. 2011 - Application of persistent scatterers interferometry for landslide monitoring in the vicinity of Roznow Lake in Poland. Acta Geodyn. Geomater., 8 (3): 319-323.

PERSKI Z., NESCIERUK P., WOJCIECHOWSKI T. 2019 - Zagrożenia osuwiskowe dla sztucznych zbiorników wodnych w Karpatach. Prz. Geol., 67 (5): 332-338.

PERSKI Z., WOJCIECHOWSKI T., MARINKOVIC P., MICHALSKI A., NESCIERUK P., WÓJCIK A. 2015 - Trójwymiarowa charakterystyka pola deformacji osuwiska $\mathrm{z}$ wykorzystaniem interferometrii satelitarnej wysokiej rozdzielczości oraz pomiarów in-situ na przykładzie osuwiska Just. Ogólnopolska Konferencja O!suwisko 19-22 maja 2015, Wieliczka. Mat. konf.: $59-60$

POPRAWA D. 1969 - Karta dokumentacyjna osuwiska nr 65/2. Osuwisko w miejscowości Zagórze, powiat nowosądecki, województwo krakowskie. Nar. Arch. Geol., PIG-PIB.

POPRAWA D., RACCZKOWSKI W., KOPCIOWSKI L., NESCIERUK P., ZIMNAL Z., DZIEPAK P., MROZEK T. 1997 - Prace geologiczne dla rejestracji osuwisk i innych zjawisk geodynamicznych na terenie województwa nowosądeckiego i tarnowskiego powstałych w wyniku katastrofalnych opadów i powodzi. Arch. Państw. Inst. Geol.

STARKEL L. 1972 - Charakterystyka rzeźby Polskich Karpat i jej znaczenie dla gospodarki ludzkiej. Probl. Zagospodar. Ziem Górskich, 10: $75-150$.

VARNES D.J. 1978 - Slope movements: type and processes. [W:] R.L. Schuster, R.J. Križek (red.), Landslides: Analysis and Control. Transport. Res. Board, Nat. Acad. of Sci., Washington D.C., Spec. Rep., 176: 11-35. WARMUZ B., NESCIERUK P. 2019 - Dynamika przemieszczeń wybranych osuwisk w Karpatach. Prz. Geol., 67 (5): 326-331.

WOJCIECHOWSKI T. 2007 - Osuwisko w Zbyszycach. Pr. Nauk. Inst. Gór. Polit. Wroc., 120 (49): 315-324.

WOJCIECHOWSKI T., BORKOWSKI A., PERSKI Z., WÓJCIK A. 2012a - Dane lotniczego skaningu laserowego w badaniu osuwisk przykład osuwiska w Zbyszycach (Karpaty zewnętrzne). Prz. Geol., 60 (2), $95-102$

WOJCIECHOWSKI T., BORKOWSKI A., PERSKI Z., WÓJCIK A., NESCIERUK P., RĄCZKOWSKI W. 2012b - Zastosowanie lotniczego i naziemnego skaningu laserowego do badania osuwisk. II Polski Kongres Geologiczny, 17-19 września 2012, Warszawa: 91-92.

WÓDKA M. 2019 - Związek morfologii wybranych osuwisk z budową geologiczną Karpat i zapadliska przedkarpackiego w świetle analiz numerycznego modelu terenu. Prz. Geol., 67 (2): 115-122.

WÓJCIK A., PERSKI Z. 2010 - Karta rejestracyjna osuwiska w miejscowości Lipie (nr ewidencyjny 1210032-73179); http://mapa.osuwiska.pgi.gov.pl

WÓJCIK A., KOS J., JURCZAK S. 2017 - Rozpoznanie i próby zabezpieczenia osuwiska w Kurowie (Pogórze Rożnowskie, Karpaty zewnętrzne). Prz. Geol., 65 (9): 576-585.

WÓJCIK A., RĄCZKOWSKI W., NESCIERUK P. 2010 - Karta rejestracyjna osuwiska w miejscowości Znamirowice (nr ewidencyjny 1210102-22507); http://mapa.osuwiska.pgi.gov.pl

WÓJCIK A., WOJCIECHOWSKI T., WÖDKA M., KRZYSIEK U. 2015

- Mapa Osuwisk i Terenów Zagrożonych Ruchami Masowymi w skali 1:10 000, gmina Gródek nad Dunajcem, pow. nowosądecki, woj. małopolskie. NAG PIG-PIB, Warszawa.

WRZOSEK-MATL J. 1961 - Osuwiska w Polsce południowej w roku 1960. Kosmos B, 7 (2): 127-130.

WYKAZ obiektów budowlanych uszkodzonych lub zniszczonych w wyniku powodzi $\mathrm{i}$ zjawisk osuwiskowych na terenie powiatu nowosądeckiego na podstawie zgłoszeń przekazanych Powiatowemu Inspektorowi Nadzoru Budowlanego, stan na 30 listopada 2010 r.; https://bip.malopolska.pl/e,pobierz,get.html?id=478927

ZIĘTARA T. 1974 - Rola osuwisk w modelowaniu Pogórza Rożnowskiego (Zachodnie Karpaty fliszowe). Stud. Geomorph. Carp. Balcan., 8: 115-133.

Praca wpłynęła do redakcji 30.09.2019 r.

Akceptowano do druku 31.12.2019 r. 